\title{
On the new culture of time, child-rearing and acceleration civilisation
}

\section{KEYWORDS}

time, child-rearing, acceleration civilisation

\begin{abstract}
The 'more, faster, better' rule accompanies a modern child from the earliest stage of their life. Recently research on child development has become increasingly important and taken on a new dimension. Its significance lies in the capacity to provide important information about core values in child life. It also offers new development opportunities for educational environment for individuals, groups and institutions, working in the field of pedagogy, treating childhood as a common good which needs protection from increasing pressure of time and detrimental effects of acceleration civilisation.
\end{abstract}

\section{Introduction}

According to Agata Przybysz, 'Pedagogy seems to neglect the fact that the notion of "time" can be comprehended as a physical phenomenon (referring to something quantitative and objective), but also as a subjective perception, an experience of time'11 (Przybysz, 2010: 150).

Social and cultural scientists indicate that 'time is a fundamental component of social life patterns and a key cultural category’2 (Tarkowska, 1992: 22 - 23). Individuals perceive reality using the notion of time, which is an important component of every individual and group experience. Every society and every culture have a different approach to time - to its persistence, passing, and changing. ${ }^{3}$

\footnotetext{
${ }^{1}$ According to the author, social sciences focus on time only in terms of time budget and leisure time of a student; the notion of 'time' is sometimes used as a component of secret educational programs or as a category for teacher description.

2 The regulative function of time in social life has been pointed out by such sociologists as Durkheim or Giddens, as well as by many anthropologists and psychologists.

${ }^{3}$ These features of time can be best described by the category of social time, which consists of the matter of particular events and phenomena significant for certain society. This category has been widely
} 
The reflection on the role of time as a determinant in life of an individual, and on the ability to manage time in the society of 'liquid modernity's (Bauman, 2007: 6) does not inspire great optimism. Time has become a tool of regulating and organising human life, a product, which can be economised on, invested, but also lost and wasted (Sztompka, 2002: 490).

In 1825, in a letter to his friend, composer Zelter, Johann Wolfgang von Goethe warned about the pace of his times: 'Since there is always enough time if one employs it well, I succeeded now and then in doing double or triple work. (...) Time is infinitely long, and each single day is a vessel into which much can be poured if one is intent on filling it completely.' (Klein,2009: 159).

In the era of mass production and mass culture, time becomes of great value, and serves as an indicator of efficiency, which altogether affects the psychological perception of individual life and performance (Sędek, Bedyńska, 2010: 7). In the late 1960s Alvin Toffler anticipated and analysed psychological outcomes of civilisational transformations and limited human adaptability (Toffler, 1974). He pointed out changing ways in which individuals perceive surrounding reality, and experience time and obscurity of unknown situations which require quick adaptation, yet leave no time to get familiar and accustomed to them.

Speculating upon the meaning of the significance of studies on time, one might ask what is the role of interdisciplinary knowledge of time, and what is the place of studies on time in pedagogy. As a social pedagogue interested in the subject of time, I would say that there are several significant outcomes of this multithreaded research, such as provided information about threats of life in constant haste, knowledge about preservation of natural time as a common resource and child protection against time pressure, identification of abilities required to manage time, and primary values which might save young people from detrimental effects of the acceleration civilisation.

discussed by the eminent sociologist E. Tarkowska in her works, see e.g. Time in the Life of Poles: Results, Assumptions, Impressions (Czas w życiu Polaków. Wyniki badań, hipotezy, impresje), Warszawa. Tarkowska E. (1987); Time in Society: Problems, Traditions, Research Directions (Czas w społeczeństwie. Problemy, tradycje, kierunki badań), Wrocław - Warszawa - Kraków - Łódź, and The Unknown Subject: Time (On the Margins of the Work of H. Worach-Kardas: Age and Social Roles) [Temat nieznany: Czas (Na marginesie pracy H. Worach - Kardas - Wiek a petnienie ról społecznych)], „Culture and Society” („Kultura i Społeczeństwo"), XXX, No. 2 (1986).

${ }^{4}$ According to Bauman, 'Liquid life is a precarious life, lived under conditions of constant uncertainty. The most acute and stubborn worries that haunt this liquid life are the fears of being caught napping, of failing to catch up with fast moving events, of overlooking the 'use by' dates and being saddled with worthless possessions, of missing the moment calling for a change of tack and being left behind'. 
This research paper is an attempt to discuss and analyse the above questions.

\section{- Time and its interpretations}

In the Practical Dictionary of Modern Polish Language (Praktyczny Słownik Współczesnej Polszczyzny) edited by Halina Zgółkowa, we can read that time is 'an objective, continuous, measurable dimension (next to space, one of the fundamental forms of existence of matter), subjectively perceived as a succession: past - present - future': this new critical method of perceiving time pioneered by Immanuel Kant tends towards establishing the boundaries of the world of our consciousness and understanding all information of the world. The concept of time is a psychological invention of human being, enabling them to adapt to the changes in the environment (Zgółkowa, 1996: 397).

We later read that time can be understood as:

- an objective, continuous, measurable and subjectively perceived dimension;

- a succession: past - present - future;

- a distinct period either between two events or of fulfilment of an activity;

- a measure of time as (next to space) one of the fundamental forms of existence of matter;

- a grammatical category of a verb between the time of communicating and time of carrying out the action described by the verb;

- time can also describe the ambience, weather, climate.

However, in the Dictionary of Polish Language (Słownik jezyka polskiego) (Doroszewski, 2000), we can read the following meanings of the word time:

- a continuous flow of moments, continuance;

- a distinct period, a moment, when something is done or happening; a historical period

- a while, an eyeblink, a slot;

- the weather;

- a measure of astrological and geographical time.

Time can thus be presented in a variety of interpretations. Time flows, runs out, heals, erases memories. Time can be lived through and experienced in many ways. A good example is the deliberation of the eminent sociologist Jan Szczepański. According to him, time is defined differently by healthy individuals, as they fill it with work, family, and entertainment. Human beings who are helpless in the face of time, lonely, sick, in a difficult situation, or with no option to act, have to deal with time themselves. 'Time', Szczepański writes, 'is a set of all strengths, destroying everything that exists' (Szczepański, 1984: 316-317). In the experiences of a powerless individual, the mentioned author seeks the magnitude of time - we 
often tend to forget what strength it takes to live and cope with the flowing time in times of helplessness and vulnerability.

Time can be described, among other things, as created, regulated, controlled, historical, constructed. Time is an unavoidable aspect of social life and cultural being. Time is connected to God, the universe, it is everywhere, it penetrates our lives, along with the past, the present and the future (Adam, 2010). Here it is worth mentioning that, since recently, the phenomenon is being inspected by multidisciplinary studies on time.

Time takes many forms, which is why we have multiple classifications of it. One of them has been provided by Wiesław Sztumski, who divides time into the real and the virtual. The first concerns objects existing in the real world, while the other - objects that belong to the virtual world, which is the realm created through computing. The mentioned author further divides real time into the natural (environmental) and artificial (cultural). The named classifications penetrate and influence each other (Sztumski, 2010: 26-28).

In the past, natural (environmental) time had a dominating influence over the life of humans. Today, cultural (artificial) time, which shapes our lives, has an increasingly large significance in forming our living environment. The current situation has been substantially influenced by the ideology of consumerism and the cult of money. W. Sztumski writes that 'We are slaves to money, which has become the god of capitalism and the common object of cult' (Ibidem).

The feeling of rush is born in our consciousness, which operates according to our internal (endogenous) time. External (exogenous) time also exists. Internal time is unaffected by the mechanical and biological clocks. Consciousness creates a time of its own. To better operate with time, scholars recommend first understanding the laws of internal time. Internal clocks are located in the human organisms and are connected directly to their vital functions.

The functioning of internal (endogenous) clocks is influenced by:

- Internal (endogenous) rhythms - processes and phenomena, which are cyclically repeated in the organism;

- External (exogenous) rhythms - processes and phenomena, which are repeated in animate and inanimate nature;

- Factors of the natural environment, such as light, temperature (Ibidem).

The human internal clock has the following characteristics: it is autonomous; it is resistant to temperature change; it can be changed; it has a limited flexibility; it is the coordinator of events and it is genetically controlled (Sztumski, 2010: 33). However, it is the human individual who has the freedom of choosing how they wish to utilize their time and how they wishes to perceive the rhythm of life. 
In social studies (predominantly sociology and psychology), time is understood as a subjective perception. This experience of time is sometimes referred to as 'social time'. Time can also be described as a social phenomenon. The dynamism of social life is characterised by the persistent human activity, the undergoing of change and the unfolding processes. All social phenomena happen at a time, in a certain moment, and last for a certain while. No social phenomenon is isolated, individual or separate (Sztompka, 2002: 474-475). It was the sociologists, predominantly representatives of the classic French sociological school, prominent explorers of time: Emile Durkheim, Marcel Mauss, Henri Hubert and Marcel Halbwachs, who have determined that time is a 'social fact', the emancipation of social life, created thanks to the collective human forms of existence. It is not only a cognitive category but also a social construct, which at the same time regulates and directs human action. Time simultaneously expresses and establishes the rhythm of social life. It is related culturally (Hall, 1999) and historically. From this perspective, time is a network of relations, which reflect and shape the temporary dependencies between phenomena or social actions (Ibidem).

There have also been different concepts of time and different approaches to the problematics of time throughout the historical periods and culture types. There are also concepts of time accepted by each of the sciences. The times of a physicist, mathematician, biologist, sociologist, psychologist and historian are all different. There are also many different ways to define time. Thus, there is not only one time, but many, all of a different nature (Pawełczyńska, 1986: 17-18).

\section{- The acceleration civilisation - new phenomena, new problems}

The acceleration civilisation is inseparably connected to the technological progress, which dictates a new system of values and perspectives of further progress. The occurrence of phenomena that threaten human life and health, and the environment, worries many scientists. The temporality and processuality of the phenomena of the modern world, especially the influence of the racing globalisation and the ideology of consumerism, change human behaviour and significantly affect human's everyday functioning.

Every parent tries to establish advantageous living conditions to enable them to live a decent life and raise children. Modern, quickly developing technological civilisation (Pawełczyńska, 1986) on one hand allows for possibilities and opportunities to raise levels of human living conditions, but on the other it has evolved into a being independent from its creator, the human. The specificity of technological civilisation is characterised by the economic and consumerist goals and motivations, in relation to which, according to A. Pawełczyńska, a hierarchy of values and its interconnected quantitative time are formed, which begin to take the form 
of a measure of acceleration of work effectiveness, but also of career, of (material and individual) success, of almost everything. They become the ally and, at the same time, the enemy of an individual (Pawełczyńska, 1986: 164-169).

Technological civilisation and its consumerist culture have developed a supreme significance of materialistic values, which are measured and counted, in which the human takes an instrumental position (Ibidem). Thus, the individual lives in a world of things, and the meaning of their life has shrunk to gaining things and drawing pleasure from it. Securing the necessary materialistic conditions becomes a priority goal, which creates consumerist attitudes, weakening the significance of the spiritual needs of an individual and limiting the opportunities for their personal development. A society occupied by parents and their children is 'a society of excess and extravagance, a society of redundancy and wastefulness. The more fluent its structure, the more people need consumption items to secure themselves from the blind blows of fate (which, in the language of sociology, are called unforeseen consequences of actions)' (Bauman, 2007: 132).

The acceleration civilisation is accompanied by the pressure of the moment, waste of time and an insistent attempt to 'be up-to-date.' Parents begin to live according to the 'more, faster and better' rule and pass these values on to their children. The youngest generation is being raised in a world where the 'trade-off' rule reigns, which has fatal consequences for adolescent development. In the restless everyday life there is no time for reflection, pursuit of understanding and experiencing the world, or to be a child with a family. Completely and casually swappable, like shirts - as Zygmunt Bauman says - (late) modern identity is not simply one of its common variants, an innocent mutation, but a destructive effect of a barbaric time (Ibidem).

A worrying process of 'mixing', as Lesław Hostyński would say, of different types of values (Hostyński, 2006: 402) has occurred, with the individuals focused predominantly on the materialistic qualities. The following devaluation of values displays a moral distribution, which shows its mark in the raising process, which is, according to the social pedagogue T. Pilch, the only way of 'building and improving a human.' According to the mentioned author,

- we are living in a world of rivalry instead of cooperation as an imperative of modern culture;

- we show a neurotic need of success or a cultural obsession with victory (as Aronson calls it);

- currently, work effectiveness becomes the measure of an individual, replacing the rule 'that a human being is the measure of all things';

- freedom is more important than responsibility; 
- the Technopolis model dominates the humanist model;

- the inequality of share and access is deepening;

- corporative selfishness and isolation instead of unity;

- social disintegration caused by indifference and helplessness, and

- capital speculation as a source of wealth instead of work is noticed (Marzec - Holka, Guzy - Steinke, Joachimowska, Rutkowska, 2010: 58).

As an effect of the discussion over the state of family, unity and culture, T. Pilch writes: 'from the point of view of social pedagogy, analysis of the family (...), country as a unity implementing social policy, and culture, especially mass culture, creates an empirical chance of evaluation of their significance in the raising process and for the development of the nature and quality of value systems, which are now exceptionally heavily shaped by mass culture' (Pilch, 2007: 92). Today, means of mass communication have worryingly appropriated the 'role of the demiurge of social imagination and the creator of norms of social behaviour' (Ibidem).

In the unhealthy everyday life, parents and their children begin to function in a psychosis of fully making use of every hour. In the words of Albin Klein, they take part in 'an enormous test of handling time, which there is constantly too little of, even though no generation before has had so much free time to spend' (Klein, 2009: 155-165). In a consumerist society, time becomes a scarce good.

Stefan Klein presents the results of the research conducted in 2005 for the Forsa association, which show that as many as 67 percent of Germans state that 'the main reason behind stress is the constant rush and worrying. 'Rush affects women the most: 60 percent of them had children, and 83 percent had a job, which lets us establish that time deficit has the face of a woman who tries to combine child-raising and caring for the child with a professional career. ${ }^{5}$ I think that this problem also concerns Poland.

External factors present in the modern acceleration society, such as bad moods, fear, psychical stress and the constant chase that accompanies parents, are transferred onto the children. An increasing number of stressful situations in their everyday life is also connected to the need to adapt to the fast-paced changes in work and in life, and to be ready to solve difficult life problems.

Professionally active parents now need to not only fulfil the requirements of their jobs but also recognize and meet the needs of their children. The current possibilities of adults and children to utilise gigantic resources of knowledge and creative action are limitless. Not wanting to leave anything behind, they chase the

\footnotetext{
${ }^{5}$ Providing for A. Klein: Representative survey conducted by the Forsa association for the "Stern" magazine, April 2005.
} 
flowing time. Additionally, the countless digital media content offers destroy intimacy and support the deepening process of dehumanisation of child-raising.

Modern childhood is filled with constant dynamism and change. All events, situations, people, and activities present in this development stage all have their duration and are strictly connected. The times of childhood are usually divided into family life, learning, fun and rest. The years of childhood are a creative period, which emanates from the activities of important figures. It is connected to learning, with fun that gives the child satisfaction and joy. In order to take care for their child, modern parents attempt to use this creative period to the full extent, to not waste it or lose it. They become the directors of the child's time, organising and modifying it. However, they forget that proper development of a child also relies on spending their leisure time on resting, regenerating strength, relaxation or even idleness and spending time with family. This time should enable the possibility of spending time together, which is supposed to be the basis of the development of a strong bond, love, and mutual understanding. Lack of time designated to the child's rest is connected to an important and rather old phenomenon, broadly described in German literature, for example by Michael Schulte-Markwort ${ }^{6}$ in such research papers as Burnout Kids or Super Kids, as a syndrome of child fatigue or exhaustion, which consequently leads to a child burnout. Its increasing rate of occurrence worries many pedagogues, psychologists, and child therapists, who point to a new, increasingly common phenomenon defining modern childhood.

'Ever-present economisation' is what dominates in the acceleration civilisation. The model of life under pressure is at first transferred onto the children by the parents, later by the peer group and the school. For children, this external pressure transforms into internal motivation and it often occurs that, even though the parents try to convince the child that it does not have to be the best, it does not make a difference. The internal motivation of the child is an effect of socialising and the influence of external stimuli. In the earliest years of a child life, adults inculcate children to be the best by organising their biography and investing in their education at a very early age.

\footnotetext{
${ }^{6}$ The research of Michael Schulte-Markwort concerns the phenomenon of child burnout. It has been conducted on a group of 1200 students of schools in Hamburg and proves that, for $30 \%$ of the children, school is the reason behind stress, unhappiness, and boredom. Every fifth senior year student admits that school does not give him any pleasure. Thus, school is not problematic for only $10 \%$ of students. In school, children are often subjected to disappointment in what they cannot do, which they cannot cope with without help and support. See interview with the author of the research in "Characters: Psychology Magazine" (“Charaktery. Magazyn Psychologiczny") No. 12 (239), December 2016.
} 
A peculiar phenomenon of life in a restless routine are the adults' and children's changing proportions of time distribution. Today, the professionally active parents need to not only fulfil the requirements at work but also recognise and satisfy the needs of the children. In one of her interviews, an American psychotherapist, Sue Gefhardt, has stated that 'The child needs attention. But not the attention that makes the parents satisfy their needs. It needs the attention of self-confident adults, who react to the real needs of a child, and not to their view of what the child lacks.'

\section{- Raising for the new culture of time}

Throughout the centuries, the issue of time has fascinated many thinkers looking for, as Brendon ${ }^{8}$ once wrote, 'a key to understanding the many mysterious aspects of human thought and action', but, even today, the issue is still very present and is the subject of many research works, especially within the human studies. It is being interpreted in many diverse ways, as a situation of 'cultural crisis', of 'civilisational threat' and of 'the pressure of modern times' (Tarkowska, 1987: 4), with the recognition of a quickly changing social realm, being a result of the quick changes of the ever-present economisation or compulsive consumption, which we are both witnesses to and participants of, and which has a significant influence over our actions, thoughts and living conditions.

In the current situation, unquestionably the most significant questions will be these of what to do with the time at our disposal. How do we utilise every moment of free time and manage it wisely, filling it out with valuable content?

Karl Marx once wrote that 'time is the space for human growth' (Nowicki, 1983: 149), and so time should be respected and filled with wise activities. We are now facing a new challenge, the need to prepare the young generations for the new culture of time and to use the knowledge of a studies worth mentioning - the ecology of time. The area of its research is the protection of natural time, protection of living environments and people 9 .

\footnotetext{
${ }^{7}$ Sue Gerhardt is a psychotherapist and co-founder of the Oxford Parent Infant Project (OXPIP), a pioneering charity institution, which provides psychotherapeutic help to parents and children. She is the author of Why Love Matters: How Affection Shapes a Baby's Brain (Znaczenie miłości. Jak uczucia wplywaja na rozwój mózgu).

${ }^{8}$ Providing for E. Tarkowska: S. G. F. Brandon, History, Time and Deity. A Historical and Comparative Study of the Conception of Time in Religious Thought and Practice, New York 1965, p. V.

${ }_{9}$ Wiesław Sztumski writes that 'The ecology of time was invented at the end of the 1990s. It concerns, among other things, the protection of natural time, protection of living environments and people from the destructive nature of clock time. It is a science of the mutual influences of the human and time as a component of our environment.'
} 
The already mentioned W. Sztumski, in his Turbo World, the Trap of Acceleration and the Ecology of Time (Turboświat, pułapka przyspieszenia i ekologia czasu) article, raises the issue of a threat caused by the accelerating pace of life, while at the same time underlining the need to slow it down, make it less rushed. This is important as we are most probably about to reach the limit of being able to adapt to such speeds and such rapid change, which exhaust our adaptive, bodily and intellectual capabilities. It is impossible to slow down progress, the Author says, but it can be more reasonably directed. 'For that, you need restitution of the role of natural time in the human life, along with liberation from the pressure of the artificially implemented clock time. It is all about returning to the old saying of everything in its time instead of the modern everything at the same time, in the same moment, so that we can escape from the trap of acceleration, which we have been put in by the immense progress of knowledge and technology in the $20^{\text {th }}$ century (Sztumski, 2010)'.

What is important to point out is that the acceleration civilisation can be very challenging for those who deal with educating (or pedagogically teaching) parents to change their stance and attitude towards time. An example of a good influence on the environment can be, as Mikołaj Winiarski describes it, correctly oriented environmental education. This education 'would be connected to protecting the 'world of roots' as a source of strength and taking pride in the cultural heritage' (Nikitorowicz, 2005: 28), along with a certain preparation of members of local community for the participation in the para-local and global space. The environmental education faces an urgent task concerning the broadening and spreading of knowledge regarding the local and regional environments (the nature, culture, social life, human relations, economy, political life, etc.), and spreading awareness regarding the phenomenon of globalisation, its development trends, aspects, social, cultural, educational and political implications, etc. It also concerns the shaping of an attitude of a local community open to the positive values that globalisation brings, and instrumental preparation necessary for engaged participation in solving local, regional and broader problems generated by the phenomenon of globalisation (Winiarski, 2010).

\section{Conclusions}

This research paper is merely an introduction to the subject of the new culture of time and child-reaering in the acceleration civilisation. Speculating on the contemporary condition of a modern individual, Anna Pawełczyńska concludes 
that 'most of the activities evade the pattern of a logical, well-thought-out decision, and are in fact nervous system reactions to the conditions of environment, where one can encounter various sources of frustration, conflicts and suffering. Attracted to what is vital, we lose our self-confidence, we feel tension and our chances of escape decline, and involved in new conflicts of interest, we are forced to fight. The intense pressure of consumption needs and social prestige aspirations make it difficult to fulfil one's goals completely. This is where the society takes over the task of helping individuals realise the importance of their choices, in order to protect them from uncertainty and frustration. Thus, it is essential to provide individuals (most of all children and adolescents) with knowledge framework which will help them strengthen their human resilience and let them enjoy wise choices they make on the way to protect their health and precious values.

\section{References}

Adam B. (2010). Czas, Warszawa.

Bauman Z. (2007). Płynne życie, Kraków 2007.

Brandon S. G. F. (1965). History, Time and Deity. A Historical and Comparative Study of the Conception of Time in Religious Thought and Practice, New York, p. V.

Doroszewski W. (2000). Słownik języka polskiego, (ed.), Warszawa.

Hall Edward T. (1999). Taniec życia. Inny wymiar czasu (trans. Radosław Nowakowski), Warszawa.

Hostyński L. (2006). Wartości w świecie konsumpcji, Lublin.

Klein S. (2009). Czas. Przewodnik użytkownika, Warszawa.

Marzec - Holka K, Guzy - Steinke H, Joachimowska M, Rutkowska A, (2010). Pedagog społeczny - humanista. O środowisku, rodzinie, edukacji i wartościach, [in:] Pedagogika społeczna. Przestrzenie życia edukacji (ed.) M. Konopczyński, W. Theiss, M. Winiarski, Memorial Volume Dedicated to Proffesor Tadeusz Pilch, Warszawa.

Nikitorowicz J .(2005). Próba określenia przedmiotu edukacji międzykulturowej), [in:] Region-tożsamość-edukacja, (ed.) J. Nikitorowicz, D. Misiejuk, M. Sobecki, Trans Humana, Białystok.

Nowicki A. (1983). Czas i człowiek, Warszawa.

Pawełczyńska A.(1986). Czas człowieka, Wrocław - Warszawa - Kraków - Łódź.

Pilch T.(2007). Pedagogika społeczna wobec kryzysu świata wartości, więzi i instytucji [in:] Pedagogika społeczna, (ed.) E. Marynowicz - Hetka, Warszawa.

Przybysz A. (2010). Czas w pedagogice [in:] Czas w życiu człowieka, (ed.) K. Popiołek, A. Chudzickiej - Czupały, Katowice.

Sędek G, Bedyńska S. (2010). Wprowadzenie: życie na czas. Perspektywy badawcze postrzegania czasu, (ed.), Warszawa.

Szczepański J.( 1984). Sprawy ludzkie, (ext. 3rd ed.), Warszawa.

Sztompka P.(2002). Socjologia. Analiza społeczeństwa, Kraków.

Sztumski W.(2010). Turboświat, pułapka przyspieszenia i ekologia czasu [in:] Czas w życiu człowieka, (ed.) A.Popiołek K, A. Chudzickiej - Czupały, Katowice.

Tarkowska E.(1992). Czas w życiu Polaków. Wyniki badań, hipotezy, impresje, Warszawa. 
Tarkowska E. (1987). Czas w społeczeństwie. Problemy, tradycje, kierunki badań), Wrocław - Warszawa - Kraków - Łódź.

Toffler A. (1974). Szok przyszłości, Warszawa.

Winiarski M (2010). Przedsłowie. Srodowisko życia i edukacji w perspektywie globalizacji, Animacja środowiska a edukacja i wychowanie na potrzeby jutra, (ed.) K. Segiet, K. Słupska - Kwiatkowska, Gniezno.

Zgółkowa H. (1996). Praktyczny Słownik Współczesnej Polszczyzny, (ed.), Vol. 7, Poznań. 